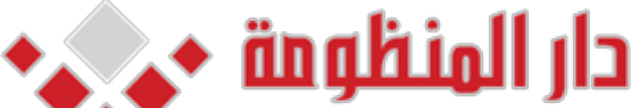 DAR ALMANDUMAH \\ السرواد
}

Myth of Performance Evaluation in Auditing Firms-



Evidence from Egypt

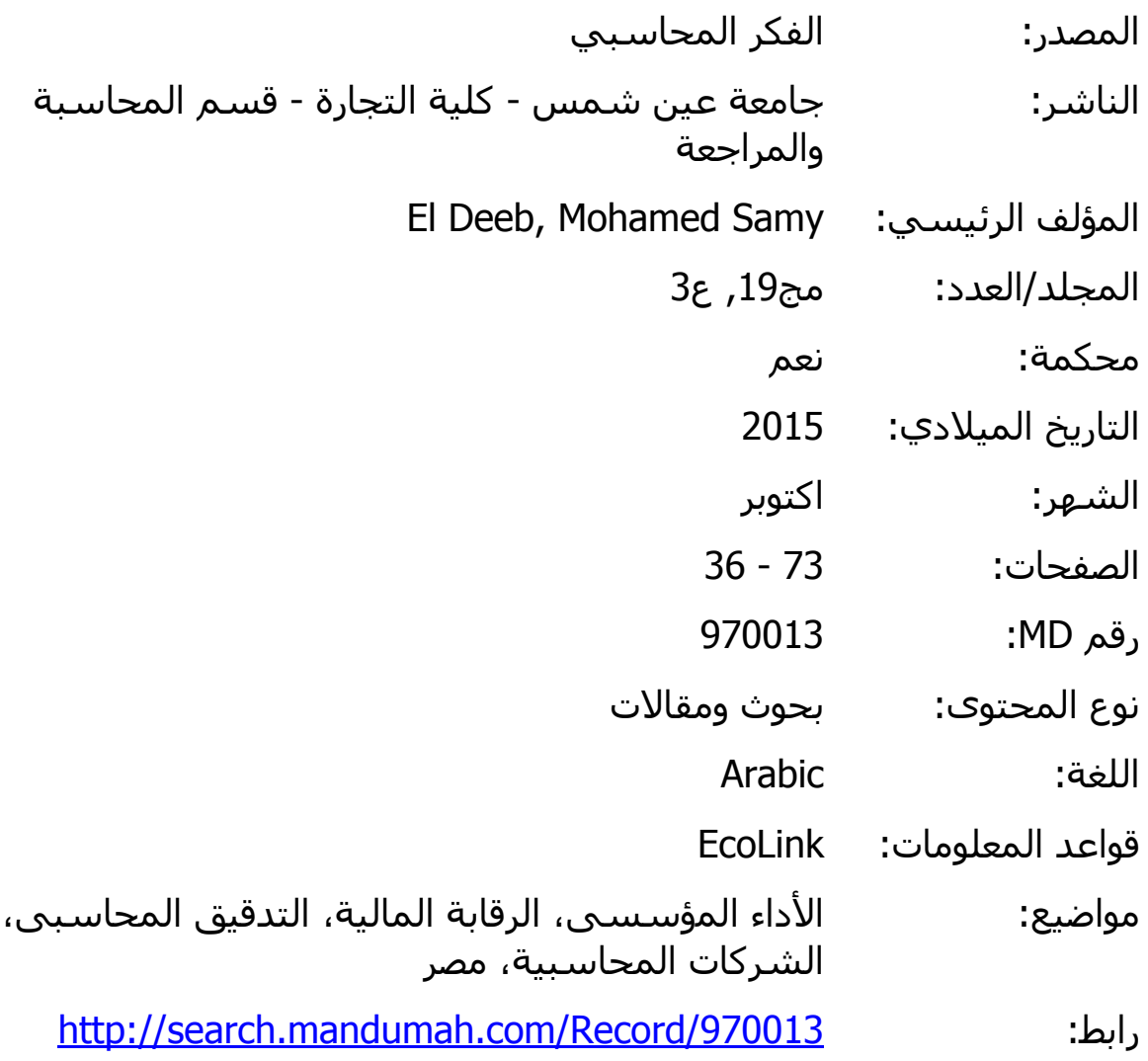


41. Sharma, M.K., Bhagwat, R. and Dangayach, G.S. (2005). Practice of performance measurement: experience from 'Indian SMEs. International Journal of Globalisation and Small Business, 1 (2), 83-213.

42. Silvestro R., Fitzgerald L., and Johnston R. (1992). Towards a classification of service processes. International Journal of Service Industry Management, 3 (3), 62-65.

43. Simon, K. and Koh, C. (2001).Balanced scorecard: a raising trend in strategic performance measurement. Measuring Business Excellence. 5 (2): 18-26.

44. Simons, R. (2000). Performance Management and Control Systems for Implementing Strategy. Prentice Hall, Englewood Cliffs, NJ.

45. Sousa, S and Aspinwall, E (2010). Development of a performarice measurement framework for SMEs. Total Quality Management \& Business Excellence. 21(5), 475501.

46. Stuart, Iris (2004). Ethics in the Post-Enron Age. SouthWestern/Thomson. p. 6.

47. Taticchi, P; Tinelli, F and Cagnazzo, L. (2010). Performance measurement and management: a literature review and a research agenda. Measuring Business Excellence, 14 (1), 418.

48. The Balanced Scorecard Institute (2010).The balanced Scorecard. [online], Available at: http://www.Balancedscorecard.org/. Accessed on 28thAugust, 2010.

49. Tsamenyi, M., Onumah, J. and Kumah, E. (2010). Post Privatisation Performance and Organizational Changes: Case Studies from Ghana. Critical Perspectives on Accounting,21(5), 428-448.

50. Yazdifar, H. and Tsamenyi, M. (2005), Management Accounting Change and the Changing Roles of Management Accountants: A comparative analysis between Dependent and Independent Organisations. Journal of Accounting and Organisational Change, 1(2), 180-198.

51.Ziegenfuss, D. (2000).Developing an internal auditing department balanced, scorecard. Managerial Auditing Journal, 15, 12-21.

52. Zimmerman, J.L., (2009). Accounting for Decision Making and Control. McGraw Hill. 
28. Kaplan, R.S. and Norton, D.P. (1996b). Using the balanced scorecard as a strategic management system. Harvard Business Review, January/February, 75-85.

29. Lee, Dong Jin, Pae, Jae H. and Wong, Y.H. (2001). A Model of Close Business Relationship in China (guanxi).European Journal of Marketing, 35, no1/12, 51-69.

30. Lynch, R.L. and Cross, K.F. (1991), Measure Up \pm the Essential Guide to Measuring Business Performance, Mandarin, London.

31. Makhamreh, M. (2000). Corporate Performance in Jordan: A Study of the Banking Sector. The Arab Bank Review, 2 (2). October. 40-48.

32. Marr, B. and Neely, A. (2001). The Balanced Scorecard Software Report. Gartner, Stamford, CT, and Cranfield School of Management, Cranfield.

33. Marr, B. and Schiuma, G. (2003). Business performance measurement - past, present and future.Management Decision, 41, 680-687.

34. Merchant, K.A and Van der Stede, W.A (2007) Management control systems: performance measurement, evaluation and incentives 2nd, Prentice Hall, Harlow, UK. ISBN 9780273708018

35. Nachum, L. (1999) The Origins of the International Competitiveness of Firms: The Impact of Location and Ownership in Professional

36. Neeley, A (2005). The evolution of performance measurement research: developments in the last decade and a research agenda for the next. International journal of Production and Operations Management,25 (2) pp 1264-1277.

37. Neely, A. (1999).The Performance Measurement Revolution: why now and what is next? International Journal of Operations and Production Management, 19 (2), 205-228.

38. Otley, D, T and Berry, A.j. (1998) Case study research in management accounting and control. Accounting Education, 7, S105-S127.

39. Paranjape, B; Rossiter, $M$ and Pantano, P. (2006). Insights from the balanced, scorecard performance measurement systems: successes, failures and future-a review. Measuring Business Excellence, 10 (3).

40. Scapens, R.W., Ezzamel, M., Burns, J. and Baldvinsdottir, G., (2003).The Future Direction of UK Management Accounting Practice. Elsevier/CIMA publications, London. 
14. Foster, G (1986). Financial statement analysis. 2nd edition Prentice Hall

15. Gray, I., and Manson, S (2007). The audit process, principles, practices and cases.4th Ed. Thompsons.

16. Mohamed, $\mathrm{H}$ and Mayada; T. (2015). "Performance Measurement Systems in Auditing Firms: Challenges and Other Behavioural Aspects". Journal of Accounting in Emerging Economies (forthcoming).

17. Hoffjan, A., Wömpener, A., 2006. Comparative analysis of strategic management accounting in German- and Englishlanguage general management accounting textbooks. Schmalenbach Business Ruview 58, 234-258

18. Hope, J. and Fraser, R. (2001). Figures of Hate. Financial Management, 22- 25.

19. Hoque, Z. (2003). Strategic Management Accounting.2nd Edition. London: Spiro Press.

20. Horngren, T. Datar, S and Foster, G. (2005). Cost accounting: A managerial emphasis. 12thedition. Pearson Inc.

21. Jackling, Beverly; Barry J. Cooper; Philomena Leung; Steven Dellaportas (2007). "Professional Accounting Bodies' Perceptions of Ethical Issues, Causes of Ethical Failure and Ethics Education" . Managerial Auditing Journál 22 (9): 928-944

22. Johnson, H.T. and Kaplan, R.S. (1987). Relevance Lost: The Rise and Fall of Management Accounting. Boston: Harvard Business School Press.

23. Johnston, R, Brigall. S and Fitzgerald .I. (2002).' Good enough' performance measurement: a trade-off between activity and action. Journal of the Operational Research Society.53 (3), 256-262.

24. Johnston, R. (1988) service industries- improving competitive performance. The Service Industry Journal. 8 (2).

25. Kaplan, R and Norton, D (1992). The balanced scorecardmeasures that drive performance. Harvard Business Review, 71-72

26. Kaplan, R. \& Norton, D. (1996). The balanced scorecard. Harvard Business Press.

27. Kaplan, R.S. and Norton, D.P. (1996a).Translating Strategy into Action. The balanced scorecard. Harvard Business School Press, Boston, MA. 


\section{References}

1. Abdul Khalid, S.N. (2000). An institutionalised study of resistance to management accounting change. $\mathrm{PhD}$ Thesis (Unpublisheci), Manchester School of Accounting and Finance.

2. Arens, A., Elder, R. and Beasley, M. (2013).Auditing and Assurance Services: an Integrated Approach. Pearson, 14th Edition.

3. Berliner, $C$ and Brimson, J.A (1998). Cost management for today's advanced manufacturing. Harvard Business School Press.

4. Berman, E. and Wang, X. (2000). Performance Measurement in U.S. Counties: Capacity for Reform. Public Administration Review. 60(5). 409-420.

5. Bromwich, Michael and Alnoor Bhimani (1994), Management Accounting: Pathways to Progress, Oxford: Butterworth Heinemann.

6. Cadez, S., \& Guilding, C., (2007). Benchmarking the incidence of strategic management accounting in Slovenia. Journal of Accounting and Organizational Change, 3, 126146.

7. Cohen, S. Thiraios, D and Kandilorou (2005).Performance parameters interrelations from a balanced scorecard perspective an analysis of Greek companies. Managerial auditing journal.23 (5), 485-503.

8. Cooper, S. Crowther, D, Davies $M$ and Davis E.W. (2001).Shareholder or stakeholder value: the development of indicators for the control and measurement of performance. London: CIMA.

9. Cross, K. and Lynch, R. (1992). For good measures. MA magazine. 20:23.

10. Eccles, R. (1991). The performance measurement manifesto. Harvard business review, 131-137

11. Fincham, R., Roslender, R., 2003. Intellectual capital accounting as management fashion: a review and critique. European Accounting Review 12:4, 781-795.

12. Fitzgerald, L. (2007). Performance Measurement. Chapter 11 (in Hopper, T., Northcott, D. and Scapens, B. Issues. in Management Accounting3rd Edition, FTC Prentice Hall.

13. Fitzgerald, L. and Brignall, S. (1991). Performance .... Measurement in Service Business. Chartered Institute of Management Accounting. 


\section{Conclusion}

This research aimed at answering two main questions: what are the components of auditing balanced scorecard in an auditing firm and is the proposed model valid for the Egyptian audit firms. The proposed auditing balanced scorecard was tested and verified by using. a questionnaire that was distributed to four auditing firms. The results of : the data collection were analyzed using group of statistical techniques (Descriptive analysis, Pearson correlation, and Stepwise multiple linear regression).

The descriptive and statistical analysis of the developed BSC measures showed the importance of the five components of the BSC with a mean greater than 4. Also, the rank analysis shows the consensus on the five components anong the survey respondents according to the values of the Co-efficient of variation. The Pearson correlation matrix indicate that there are significant positive relationship among the dimensions of the proposed BSC model and the level of expected performance of the auditing firms at significant less than (0.001).

The results of the regression analysis provide support for the research questions and related hypotheses confirming the validity of BSC measures and their effect on audit work. The constructs and measures of the proposed auditing balanced scorecard are explaining $91 \%$ of the expected performance of the Egyptian auditing firms as regression analysis showing $\left(\mathrm{R}^{2}=91.30 \%\right)$. Both large and medium firms can use the auditing BSC though some adaptation would be required to make it useful to individual organizations. 


\section{8}

By substituting the mean values of the independent variables as shown in table (3) in the above regression model, learning and growth, internal business process, financial perspective, client and corporate ethics perspectives by (4.2616), (4.2071), (4.1112), (4.1041), and (4.1544) respectively and according to Likert scale (1-5), we can then predict the Level of performance for the auditing firms. The Level of firm's performance is (4.569) and thus we have above satisfactory direction (3.40) to the level of performance for the auditing firms. The regression model shows the effect of the five elements of the model on the performance of the auditing firms. This can help auditing firms to both enhance their performance and identify the different problems that affect the quality of the auditing firms.

From the regression analysis, the researcher verified the third hypothesis by introducing the regression model that can show the effect of applying the proposed model variables (measures) in auditing firms on the performance of these companies. This means that the developed measures in the proposed model of BSC can enhance the performance of the audit work.

As to the effect of the above analysis on the research hypotheses, the results provide partial support for $\mathrm{H} 1$ indicating that the components of the BSC for auditing firms will be different than the BSC for any service organization. This was evidenced in the results of the descriptive analysis indicated the consensus of the respondents on the measures proposed by the researcher. Also, the use of the correlation matrix (Pearson correlation) indicated the significant relationships among perspectives of the proposed measures and the level of the performance of auditing firms in relation to the application of each perspective and as an overall to the performance of the auditing firms. The regression analysis added a new dimension to the results where it identified the impact of each of the perspectives within the proposed $\mathrm{BSC}$. Finally, as to $\mathrm{H} 2$ and $\mathrm{H} 3$ which indicates that the developed measures in the proposed model of BSC for audit firms will enhance the performance of the audit work, the results indicated that the variables representing the BSC measures explain (91.30\%) from total variation of dependent variable, which is the performance of the auditing firms and the rest percent due to either the random error in the regression model or other Independent Variables excluded from regression model. 
table (10) show that the value of VIP is less than 4; therefore the model is not affected from the multicollinearity problem.

Moreover, the Normal Probability Plot shows that according to regression assumptions, the estimation of the model parameters require the errors normally distributed with mean equal (zero) and variance equal (1), and the model fits the assumption with mean equal (zero) and variance equal (0.985).

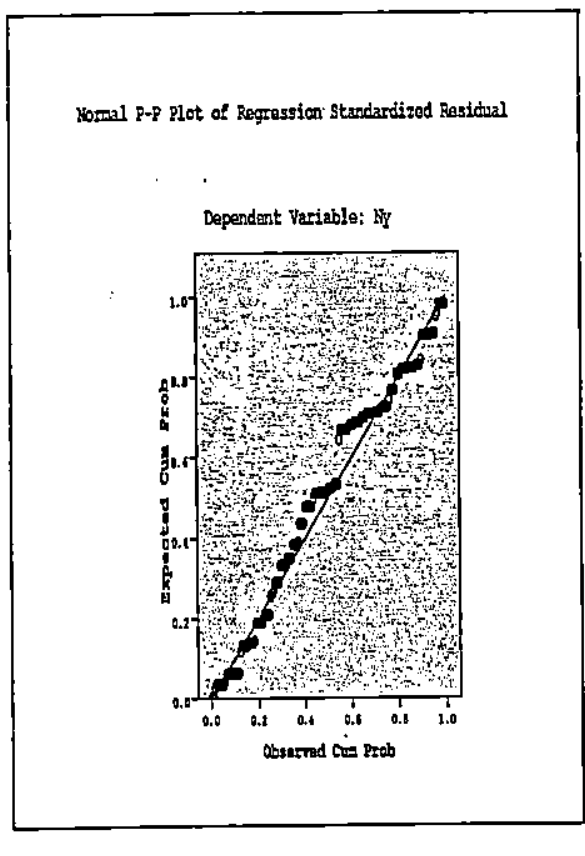

Figure 4: Plot of regression standardized residual

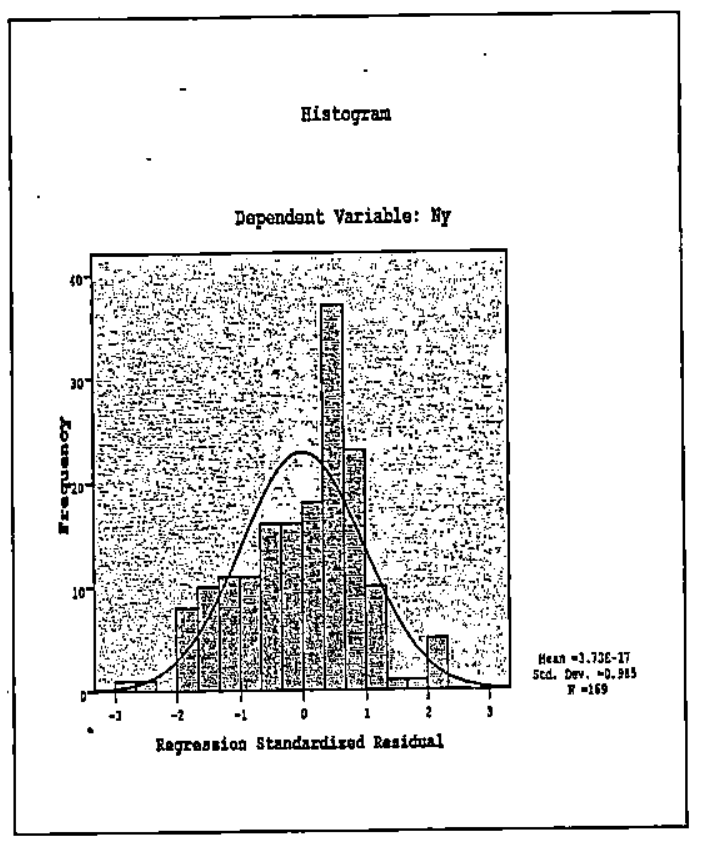

Figure 5: Histogram of regression standardized residual

Finally, the Regression model can be presented as follows:

Level of performance for the auditing firms=

$-0.857+0.135$ Learning and growth +0.421 Internal business process +0.138 Financial perspective +0.350 Client perspective +0.259 Corporate Ethics perspective. 


\section{6}

Table (10): Stepwise multiple linear regression model to

determine the most significant dimensions of BSC model and the audit firms level of performance

\begin{tabular}{|c|c|c|c|c|c|c|c|c|}
\hline \multirow{2}{*}{ VIF } & \multirow{2}{*}{$\begin{array}{l}\mathbf{R}^{2} \\
\%\end{array}$} & \multicolumn{2}{|c|}{$\mathrm{F}$ test } & \multicolumn{2}{|c|}{$t$ test } & \multirow{2}{*}{$\begin{array}{l}\text { Estimated } \\
\text { coefficient }\end{array}$} & \multirow[t]{2}{*}{ Independent Variables } & \multirow[t]{2}{*}{ No } \\
\hline & & Sig. & vaiue & Sig. & value & & & \\
\hline- & 91.3 & $0.001 * * *$ & $341.1 . ; 5$ & 0.001 *** & -7.899 & -0.857 & constant & \\
\hline 1.747 & & & & $0.001^{* * *}$ & 4.232 & 0.135 & $\begin{array}{l}\text { Learning and growth } \\
\text { perspective }\end{array}$ & 1 \\
\hline 2.233 & & & & $0.001^{* * * *}$ & 12.242 & 0.421 & $\begin{array}{l}\text { Internal business process } \\
\text { perspective }\end{array}$ & 2 \\
\hline 1.147 & & & & $0.001^{* * \ldots}$ & 5.543 & 0.138 & financial perspective & 3 \\
\hline 1.276 & & & & $0.001^{* * * *}$ & 13.543 & 0.350 & Client perspective & F \\
\hline 1.428 & & & & $0.001^{* * * *}$ & 9.315 & 0.259 & Corporate ethics perspective & 5 \\
\hline
\end{tabular}

** Parameter is significant at the (.01) level

$* * *$ Parameter is significant at the (.001) level

In relation to Coefficient of determination in multiple linear regression model, table (10) shows that the independent variables proposed in the model (i.e., Learning and growth, internal business process, financial, client and corporate ethics perspectives explain (91.3\%) from total variation of the dependent variable (i.e., the level of performance of the auditing firms), the remaining percentages due to either the random error in the regression model or other independent variables excluded from the regression model.

Similarly, $t$ test is useful in determining the significant value of each of the individual independent variables coefficient in the regression model. The significant independent dimensions accepted in the model are: learning and growth, internal business process, financial, client and corporate ethics perspectives with significant level at less than $(0.001)$. The $F$ test helps to determine if there is a linear relationship between the dependent variable ( $y$ ) and a subset of the independent variables. The value of "F test" is (341.165) with significant level at the (.001) level. The above results help the researcher to conclude that the independent dimensions were accepted in the model and have affected the level of performance for the auditing firms. Also, the Variance Inflation Factors (VIF) are useful measures of multicollinearity; the larger the variance inflation factors, the more severe the multicollinearity. Some authors have suggested that if any variance inflation factors exceed 10 , the multicollinearity is a problem. Other authors consider this value too liberal and suggest that the variance inflation factors should not exceed 4 or 5 . The results in 
Table (9): Correlation matrix to measure the significant relationships among dimensions of proposed BSC model and level of performance for the auditing firms

\begin{tabular}{|c|c|c|c|c|c|c|}
\hline $\begin{array}{l}\text { Dimensi } \\
\text { ons }\end{array}$ & $\begin{array}{l}\text { Performa } \\
\text { nce }\end{array}$ & $\begin{array}{c}\text { Learning } \\
\text { and } \\
\text { growth } \\
\text { perspec } \\
\text { tive }\end{array}$ & $\begin{array}{c}\text { Internal } \\
\text { business } \\
\text { process } \\
\text { perspec } \\
\text { tive }\end{array}$ & $\begin{array}{c}\text { Financia } \\
\text { perspec } \\
\text { tive }\end{array}$ & $\begin{array}{c}\text { Client } \\
\text { perspec } \\
\text { tive }\end{array}$ & $\begin{array}{l}\text { Corpor } \\
\text { ate } \\
\text { ethics }\end{array}$ \\
\hline & 1 & 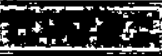 & 7 & & & \\
\hline $\begin{array}{l}\text { Learning } \\
\text { and } \\
\text { growth } \\
\text { perspect } \\
\text { ive }\end{array}$ & $0.626^{* * *}$ & 1 & 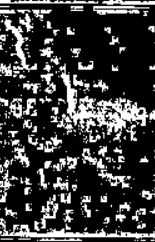 & & & \\
\hline $\begin{array}{l}\text { Internal } \\
\text { business } \\
\text { process } \\
\text { perspect } \\
\text { ive }\end{array}$ & $0.841^{* * *}$ & $0.639^{* * *}$ & 1 & & & \\
\hline $\begin{array}{l}\text { Financial } \\
\text { perspect } \\
\text { ive }\end{array}$ & $0.456 * * *$ & $0.221^{* *}$ & $0.325^{* * *}$ & 1 & & \\
\hline $\begin{array}{l}\text { Client } \\
\text { perspect } \\
\text { ive }\end{array}$ & $0.680^{* * *}$ & $0.237^{* * *}$ & $0.444^{* * *}$ & $0.241^{* * *}$ & 1 & $F^{4}-407$ \\
\hline $\begin{array}{l}\text { Corpora } \\
\text { te Ethics }\end{array}$ & $0.671^{* *}$ & $0.435^{* * *}$ & $0.517^{* * *}$ & $0.264^{* * *}$ & $0.287^{* * *}$ & 1 \\
\hline
\end{tabular}

***C Correlation is significant at the 0.001 level (2-tailed).

According to correlation Matrix results shown in Table (9), it is revealed that there are significant positive linear relationships among the dimensions of the proposed BSC model and the level of performance of the auditing firms at significant less than (0.001). At the same time, the results of the stepwise multiple linear regression models needed to explore the most significant dimensions of proposed BSC model and level of performance for the auditing firms are presented in table (10). 


\section{4}

countries in terms of seeing the importance of union relations and ability to apply organized strikes to seek the interests of their employees. This element is looked at by respondents as not affecting significantly the corporate ethics perspective. At the same time, criminal records are considered not acceptable by respondents and therefore you cannot expect to find an employee in an audit firm with current or previous criminal records as-losing the integrity and honesty in the audit service means that such an employee is out of the audit profession. As long as the relationship between the audit firm and its employees are organized through written contracts, employees do not consider employees policies or resignation as affecting the performance of the audit service. In sum, the value of total weighted mean for Learning and growth perspectives (4.1544), with coefficient of variation $(13.05 \%)$, therefore we have sometimes direction to the Learning and growth perspective.

From the previous statistical analysis results the researcher verified the second hypothesis; which mean that the balanced scorecard is a viable technique to be used in the auditing firms as long as the five perspectives of the proposed model to measure the performance of auditing firms are acceptable and answers of the respondents' mean are tending to be over 4 . The analysis also, provided a rank for the different measures (variables) within each perspective.

\section{3- Pearson Correlation:}

To test the most significant dimensions of the proposed BSC model that affect thelevel of performance for the auditing firms, the researcher use the following two statistical techniques: Pearson Correlation matrix to assess the significant relationships among dimensions of the proposed BSC model and the level of performance for the auditing firms and the confirmatory factor analysis to explore the most significant dimensions of the proposed BSC model that affects the level of the performance of the auditing firms. 
therefore we have sometimes direction to the Learning and growth perspective.

\section{5-Corporate Ethics:}

The;Descriptive statistics intable (8) related to corporate ethics show that the most three homogeneous variables lare: level of business ethics training, morale of employees and openness, ${ }^{+}$transparency with coefficient of variation $(13.42 \%),((13.87 \%)),(14: 06 \%)$ respectively. The three elements selected by respondents i to the research survey indicate the awareness of the partners, seniors 'andi auditors of the importance of ethical training of all members of an audit firm as well as the need for complete transparency : and openness in the presentation of the audit results with internal and external parties. The dishonesty in the provision of the audit services may affect the employees', morale and make'them disinterested in putting efforts and time in performing their audit responsibilities. :This is due to uncertainty in employees' believes that their findings 'would not be presented to shareholders and those responsible for governance.

Table (8): Descriptive statistics for Corporate Ethics' perspective

\begin{tabular}{|c|c|c|c|c|c|}
\hline $\begin{array}{l}\text { Question } \\
\text { NO. }\end{array}$ & statements & 'MEAN: & SD & $\mathrm{CV}$ & RANK \\
\hline 1 & $\begin{array}{l}\text { Level of business ethics ' } \\
\text { training }\end{array}$ & $! 4.4024$ & $0: 59080$. & 13.42 & 1 \\
\hline 2 & Morale of employees & $4: 4201$ & 0.61321 & 13.87 & 2 \\
\hline 3 & Openness, transparency & $4: 3728$ & 0.61487 & 14.06 & 3 \\
\hline 4 & Turnover rate & $4 ! 1243$ & 0:81792: & $19: 83$ & 6 \\
\hline 5 & Union relations & 33:9053 & $0 \vdots 98948$ & 25.34 & 11 \\
\hline 6 & Criminal records & $3 ! 8935$ & 0.93249 & 23.95 & 10 \\
\hline 7 & $\begin{array}{l}\text { Environmental } \\
\text { awareness }\end{array}$ & $54: 1420$ & 0.76606 & $18: 49$ & 5 \\
\hline 8 & Employee policies & 4.0000 & 0.89310 & 22.33 & 8 \\
\hline 9 & Resignations & 4.0296 & 0.89593 & 22.33 & 9 \\
\hline 10 & Employee diversity & 4.0355 & $0: 88569$ & 21.95 & 7 \\
\hline 11 & Social responsibility & 4.33728 & $0: 64326$ & 14.71 & 4 \\
\hline \multicolumn{2}{|r|}{ TOTAL. } & 4.1544 & $0: 54227$ & 13.05 & - \\
\hline
\end{tabular}

On the other hand the most three heterogeneous 'variables are: union relations, criminal records, and employee policies or resignations, with coefficient of variation (25.34\%), (23.95\%), (22.33\%) respectively. The Egyptian culture is still different from developed 


\begin{tabular}{|c|c|c|c|c|c|}
\hline 4 & $\begin{array}{l}\text { Reasonableness of the } \\
\text { audit duration from the } \\
\text { client's viewpoint }\end{array}$ & 3.7633 & 1.05935 & 28.15 & 15 \\
\hline 5 & $\begin{array}{l}\text { Providing timely } \\
\text { updates on the progress } \\
\text { of the audit }\end{array}$ & 4.2071 & 0.75495 & 17.94 & 6 \\
\hline 6 & $\begin{array}{l}\text { Presence of a "liaison" } \\
\text { point of contact } \\
\text { between the firm and } \\
\text { client. }\end{array}$ & 4.3373 & 0.55514 & 12.50 & 1 \\
\hline 7 & $\begin{array}{l}\text { Client's acceptance of } \\
\text { the fees charged. }\end{array}$ & 7,1479 & 0.76104 & 18.35 & 8 \\
\hline 8 & Brand awareness. & 3.9527 & 0.76229 & 19.29 & 9 \\
\hline 9 & $\begin{array}{l}\text { Customer retentio } \\
\text { (years of audit) and } \\
\text { repeat revenues from } \\
\text { the same client for } \\
\text { other services offered } \\
\text { (if allowed by the } \\
\text { standards) }\end{array}$ & 4.1657 & 0.70441 & 16.91 & 3 \\
\hline 10 & $\begin{array}{l}\text { Percentage of new } \\
\text { customers }\end{array}$ & 4.1183 & 0.72224 & 17.54 & 5 \\
\hline 11 & Customer referral. & 4.3314 & 0.72146 & 16.66 & 2 \\
\hline 12 & $\begin{array}{l}\text { Success or failure of } \\
\text { project tendering }\end{array}$ & 3.7929 & 0.79339 & 20.92 & 12 \\
\hline 13 & Market share & 4.0710 & 0.83505 & 20.51 & 11 \\
\hline 14 & Lost clients. & 4.0296 & 0.84815 & 21.05 & 13 \\
\hline 15 & Number of new clients & 74.2012 & 0.72028 & 17.14 & 4 \\
\hline & TOTAL & 4.1041 & 0.48560 & 11.83 & -- \\
\hline
\end{tabular}

On the other hand, the most three heterogeneous variables are: reasonableness of the audit duration from the client's viewpoint, clients having easy access to partners for any enquiries or advice, and lost clients, with coefficient of variation (28.15\%), (22.99\%), $(21.05 \%)$ respectively. Again, respondents assessed the elements of the client's perspective from their own interest and benefits. They ignored the importance of the above elements ${ }^{2}$ which are considered important for the retention of the existing clients and acquiring new clients. In sum, the value of total weighted mean for Learning and growth perspectives (4.1041), with coefficient of variation $(11.83 \%)$, 


\section{1}

On the other hand the most three heterogeneous variables are: number of charity organization audited, Feedback controls such as variance analysis and reduction in cost of key areas, Budgets and actual cash flows available for training, developments and other improvements, with coefficient of variation (30.53\%), (20.41\%), (19.37\%) respectively. A possible interpretation of the above results is that respondents believed that the number of charity audited, payment of taxes and cash flows are a by-product of the audit firm making adequate profit and being able to secure liquidity by collecting its receivables on due dates. In sum, itis seen that the value of total weighted mean for learning and growth perspectives (4.112), with coefficient of variation $(10.29 \%)$, therefore we have sometimes direction to the Learning and growth perspective.

\section{4- Client perspective}

The results in table (7) show that the most three homogeneous variables are: Presence of a "liaison" point of contact between the firm and the client, customer referral and customer retention and repeat revenues from the same client for other services offered with coefficient of variation $(12.80 \%),(16.66 \%),(16.91 \%)$ respectively. Direct communication between the partners in the auditing firm and the client helps to ensure clients' satisfaction of the audit services. Partners can identify deficiency in the provision of the audit services by listening to management's complaints and responding with corrective actions. Clients need to consider the provision of audit services as adding value to their firms and partners should meet such objectives without affecting the integrity and independence of the audit firm. Customers' referral may include acquiring clients through words of mouth "good reputation", marketing and other media campaign. The retention of the client would require great efforts on the part of the partners in charge of the engagement. This may include providing high quality service, qualified and experienced staff, quick response to clients' inquiries, and fair fees for the engagement.

Table (7): Descriptive statistics for Client perspective

\begin{tabular}{|c|l|c|c|c|c|}
\hline $\begin{array}{c}\text { Question } \\
\text { NO. }\end{array}$ & \multicolumn{1}{|c|}{ statements } & MEAN & SD & CV & RANK \\
\hline $\mathbf{1}$ & $\begin{array}{l}\text { Customer satisfaction } \\
\text { feedback form. }\end{array}$ & 4.2012 & 0.82793 & 19.71 & 10 \\
\hline $\mathbf{2}$ & Client complaints. & 4.1420 & 0.75826 & 18.31 & $\mathbf{7}$ \\
\hline $\mathbf{3}$ & $\begin{array}{l}\text { Clients have easy access } \\
\text { to partners for any } \\
\text { enquiries or advise. }\end{array}$ & 4.1006 & 0.94267 & 22.99 & 14 \\
\hline
\end{tabular}


business process perspective is (4.2071), with coefficient of variation $(9.17 \%)$, therefore we have sometimes direction to the internal business process perspective.

\section{3- Financial perspective:}

Table (6) shows that the most three homogeneous variables are: profitability ratios, reduced receivables and growth in fees with coefficient of variation $(14.45 \%),(15.42 \%),(15.53 \%)$ r These results follow measures required for a successful business with profitability and liquidity the most significant financial measures. One of the problems which may affect the quality of the audit service provided to clients is the inability of the audit firm to collect its due fees. Audit firm needs a continuous flow of cash represented in their audit and other service fees in order to develop the firm 'internal process including IT audit, backup databases, CPE for its staff, betterautomated information and filling systems.

Table (6): Descriptive statistics for financial perspective

\begin{tabular}{|c|c|c|c|c|c|}
\hline $\begin{array}{l}\text { Question } \\
\text { NO. }\end{array}$ & statements & MEAN & SD & $\mathrm{CV}$ & RANK \\
\hline 1 & $\begin{array}{l}\text { Feed forward controls } \\
\text { such as plans, budgets, } \\
\text { standards and targets. }\end{array}$ & 4.2544 & 0.66395 & 15.61 & 4 \\
\hline 2 & $\begin{array}{l}\text { Feedback controls such } \\
\text { as variance analysis and } \\
\text { reduction in cost of key } \\
\text { areas }\end{array}$ & 4.1893 & 0.70686 & 16.87 & 6 \\
\hline 3 & Growth in fees. & 4.1775 & 0.64860 & 15.53 & 3 \\
\hline 4 & profitability ratios & 4.2840 & 0.61898 & 14.45 & 1 \\
\hline 5 & Liquidity ratios. & 4.1716 & 0.65476 & 15.70 & 5 \\
\hline 6 & $\begin{array}{l}\text { Profitability of individual } \\
\text { engagements. }\end{array}$ & 4.2604 & 0.77361 & 18.16 & 7 \\
\hline 7 & Reduced receivables & 4.1657 & 0.64254 & 15.42 & 2 \\
\hline 8 & $\begin{array}{l}\text { Budgets and actual cash } \\
\text { flows available for } \\
\text { training, developments } \\
\text { and other improvements }\end{array}$ & 4.1657 & 0.80682 & 19.37 & 8 \\
\hline 9 & $\begin{array}{l}\text { Number of charity } \\
\text { arganization audited }\end{array}$ & 3.4438 & 1.05140 & 30.53 . & 10 \\
\hline 10 & $\begin{array}{l}\text { Feedback controls such as } \\
\text { variance analysis and } \\
\text { reduction in cost of key } \\
\text { areas }\end{array}$ & 4.0000 & 0.81650 & 20.41 & 9 \\
\hline$\cdots$ & TOTAL & 4.1112. & 0.42292 & 10.29 & - \\
\hline
\end{tabular}




\begin{tabular}{|c|l|l|l|l|c|}
\hline 12 & $\begin{array}{l}\text { Issuing management } \\
\text { letter with significant } \\
\text { misstatements and } \\
\text { recommendations for } \\
\text { remedy. }\end{array}$ & 4.4024 & 0.62981 & 14.31 & 7 \\
\hline 13 & $\begin{array}{l}\text { Relationship with clients } \\
\text { during the audit including } \\
\text { being friendly to them }\end{array}$ & 4.1243 & 0.83235 & 20.18 & 13 \\
\hline 14 & $\begin{array}{l}\text { Availability of whistle } \\
\text { blowing techniques }\end{array}$ & 3.7515 & 1.10616 & 29.49 & 17 \\
\hline 15 & $\begin{array}{l}\text { No errors or mistakes } \\
\text { detected after } \\
\text { completing the } \\
\text { engagements }\end{array}$ & 3.4024 & 1.18683 & 34.88 & 18 \\
\hline 16 & $\begin{array}{l}\text { Another partner verifying } \\
\text { results of the service and } \\
\text { approving them (peer } \\
\text { review). }\end{array}$ & 4.0533 & 0.88815 & 21.91 & 14 \\
\hline 17 & $\begin{array}{l}\text { Meeting the engagement } \\
\text { timetable deadline (to } \\
\text { measure efficiency) }\end{array}$ & 3.8698 & 0.85613 & 22.12 & 15 \\
\hline 18 & $\begin{array}{l}\text { Cost of the audit (to } \\
\text { measure efficiency) }\end{array}$ & 4.3254 & 0.74443 & 17.21 & 10 \\
\hline & TOTAL & 4.2071 & 0.38565 & 9.17 & - \\
\hline
\end{tabular}

On the other hand the most three heterogeneous variables are: no errors or mistakes detected after completing the engagements, availability of whistle blowing techniques, and recording and updating working papers both manually and electronically with coefficient of variation $(34.88 \%),(29.49 \%),(23.14 \%)$ respectively. The above results show the unawareness of the respondents of the need to have a good follow up process after the completion of the audit to ensure proper documentation of the audit and the review of the results achieved to ensure no errors or misstatements were not detected based on audit evidence. As to the whistle blowing tool, the Egyptian culture is lacking the notion of transparency and full disclosure as respondents still believe that it is an unethical behaviour if one complained about deficiency or unethical conduct made by one of his colleagues. Although Koran motivates Moslems to be honest and maintain their integrity in their work and life, the culture of the Egyptian environment still outweighs these religion and ethical concepts and measures. In sum, as the value of total weighted mean for internal 


\section{8}

the quality control in providing auditing services as well as ethical behavior of the auditors at all levels in every audit firm. The qualification, experience and continuous training of the audit staff are considered important elements in the internal business process of any balanced scorecard.

Table (5): Descriptive statistics for internal business prusess perspective

\begin{tabular}{|c|c|c|c|c|c|}
\hline $\begin{array}{l}\text { Question } \\
\text { NO. }\end{array}$ & statements & MEAN & SD & $\mathrm{CV}$ & RANK \\
\hline 1 & $\begin{array}{l}\text { The ability of the firm to } \\
\text { acquire highly skilled } \\
\text { staff }\end{array}$ & 4.4793 & 0.56788 & 12.68 & 3 \\
\hline 2 & $\begin{array}{l}\text { Independence, integrity } \\
\text { and objectivity measures. }\end{array}$ & 4.5680 & 0.50866 & 11.14 & 2 \\
\hline 3 & $\begin{array}{l}\text { Acceptance and } \\
\text { continuation of clients } \\
\text { and engagements. }\end{array}$ & 4.0947 & 0.74196 & 18.12 & 12 \\
\hline 4 & $\begin{array}{l}\text { Planning of the } \\
\text { engagement and time } \\
\text { taken for preparing the } \\
\text { plan. }\end{array}$ & 4.2959 & 0.58354 & 13.58 & 5 \\
\hline 5 & $\begin{array}{l}\text { Recording and updating } \\
\text { working papers both. } \\
\text { manually and } \\
\text { electronically. }\end{array}$ & 4.0710 & 0.94222 & 23.14 & 16 \\
\hline 6 & $\begin{array}{l}\text { Security over the client's } \\
\text { records. }\end{array}$ & 4.3373 & 0.74712 & 17.23 & 11 \\
\hline 7 & Latest technology is used. & 4.3254 & 0.73639 & 17.02 & 8 \\
\hline 8 & $\begin{array}{l}\text { Presence of a quality } \\
\text { control department for } \\
\text { monitoring adherence to } \\
\text { standards and evaluation } \\
\text { of quality (monitoring). }\end{array}$ & 4.5444 & 0.49951 & $10: 99$ & 1 \\
\hline 9 & Misstatements detected & 4.4260 & 0.59425 & 13.43 & 4 \\
\hline 10 & $\begin{array}{l}\text { Adequate supervision } \\
\text { during the engagement } \\
\text { by managers and audit } \\
\text { seniors }\end{array}$ & 4.2071 & 0.72272 & 17.18 & 9 \\
\hline 11 & $\begin{array}{l}\text { Engagement } \\
\text { performance. }\end{array}$ & 4.4497 & 0.61636 & 13.85 & 6 \\
\hline
\end{tabular}




\begin{tabular}{|c|c|c|c|c|c|}
\hline & $\begin{array}{l}\text { limits of the Auditing } \\
\text { standards) }\end{array}$ & & & & \\
\hline 12 & $\begin{array}{l}\text { Partners strategies } \\
\text { (marketịng, financial } \\
\text {...etc.) for attracting } \\
\text { new clients }\end{array}$ & $\begin{array}{l}4.3077 \\
\therefore \\
\therefore\end{array}$ & 0.58757 & 13.64 & 6 \\
\hline 13 & $\begin{array}{l}\text { use of International } \\
\text { Networks to grow and } \\
\text { learn advanced } \\
\text { accounting and audit } \\
\text { services }\end{array}$ & 4.0178 & 0.75965 & 18.91 & 13 \\
\hline \multicolumn{2}{|r|}{ TOTAL } & 4.3755 & 0.32755 & 7.69 & - \\
\hline
\end{tabular}

On the other hand the most three heterogeneous variables or elements of the learning and growth perspective are: Employee satisfaction feedback forms, System for soliciting employee suggestions and calculation of percentage of those actually implemented, and use of International Networks to grow and learn advanced accounting and audit services, with coefficient of variation $(17.11 \%),(17.47 \%)$, (18.91\%) respectively. It seems that most respondents mainly auditors and seniors would not be interested in these measures because they may not have access to such discussed information measures. Although employee satisfaction forms would result in improvement and increase in employees' remuneration, incentives and future financial packages considered the most important elements for growth and learning. Auditors and seniors are reluctant to put significant weights on these measures to minimize the risk of sudden decrease in their remunerations and incentives in situations where System for soliciting employee suggestions and calculation of percentage of those actually implemented are not achieved. As the value of total weighted mean for Learning and growth perspectives (4.3755), with coefficient of variation $(7.69 \%)$, we have sometimes direction to the Learning and growth perspective.

\section{2-2 - Internal business process:}

According to descriptive statistics presented in table, (5), the most three homogeneous variables are: Presence of a quality control department for monitoring adherence to standards and evaluation of quality (monitoring), Independence, integrity and objectivity measures, and the ability of the firm to acquire highly skilled staff with coefficient of variation $(10.99 \%),(11.14 \%), \quad(12.68 \%)$ respectively. These results confirm the trend in the accounting and auditing literature, academia and practitioners about the importance of 
Table (4): Descriptive statistics for Learning and growth perspective

\begin{tabular}{|c|c|c|c|c|c|}
\hline $\begin{array}{l}\text { Question } \\
\text { NO. }\end{array}$ & statements & MEAN & SD & $\mathrm{CV}$ & RANK \\
\hline 1 & $\begin{array}{l}\text { Emplc yee evaluation } \\
\text { forms and their uses. }\end{array}$ & 4.2485 & 0.60534 & 14.25 & 8 \\
\hline 2 & $\begin{array}{l}\text { Qualifications of } \\
\text { employees (average } \\
\text { years of audit } \\
\text { experience, hoiding } \\
\text { internationally } \\
\text { recognized } \\
\text { certificates...etc.). }\end{array}$ & 4.4970 & 0.60871 & 13.54 & 4 \\
\hline 3 & $\begin{array}{l}\text { Employee satisfaction } \\
\text { feedback forms. }\end{array}$ & 4.1657 & 0.71281 & 17.11 & 11 \\
\hline 4 & $\begin{array}{l}\text { System for solic ting } \\
\text { employee suggestions } \\
\text { and calculation of } \\
\text { percentage of those } \\
\text { actually implemented. }\end{array}$ & 4.1893 & 0.73168 & 17.47 & 12 \\
\hline 5 & $\begin{array}{l}\text { Policy for motivating } \\
\text { employees through } \\
\text { future targets and } \\
\text { financial packages. }\end{array}$ & 4.4911 & 0.57857 & 12.88 & 3 \\
\hline 6 & $\begin{array}{l}\text { Appropriate working } \\
\text { conditions. }\end{array}$ & 4.4615 & 0.63621 & 14.26 & 9 \\
\hline 7 & $\begin{array}{l}\text { strategy to increase } \\
\text { number of employees } \\
\text { with professional } \\
\text { certificates }\end{array}$ & 4.4675 & 0.62712 & 14.04 & 7 \\
\hline 8 & $\begin{array}{l}\text { Continuous } \\
\text { professional education } \\
\text { (Including training, } \\
\text { attendance of } \\
\text { seminars and } \\
\text { conferences...etc.). } \\
\end{array}$ & 4.5385 & 0.57735 & 12.72 & 2 \\
\hline 9 & $\begin{array}{l}\text { Motivating the } \\
\text { employees through the } \\
\text { prospect of becoming } \\
\text { partner }\end{array}$ & 4.7160 & 0.53656 & 11.38 & 1 \\
\hline 10 & $\begin{array}{l}\text { Speed of adapting to } \\
\text { new standards or } \\
\text { regulations } \\
\text { promulgated. }\end{array}$ & .4 .4615 & 0.60749 & 13.62 & 5 \\
\hline 11 & $\begin{array}{l}\text { Firm providing new } \\
\text { services (within the }\end{array}$ & 4.3195 & 0.63969 & 14.81 & 10 \\
\hline
\end{tabular}


More detailed analysis of the elements forming each of the components of the proposed balanced scorecard is presented in the following sections showing how each " of the components is considered by the respondents of the BSC survey.

\section{1- Learning and growth:}

Table (4) provides details about the mean, standard deviation, coefficient and ranking of the various elements forming the first component of the proposed BSC "Learning and growth". According to descriptive statistics in table (4), the most three homogeneous variables are: Motivating the employees through the prospect of becoming partner, continuous professional education, and policy for motivating employees through future targets and financial packages with coefficient of variation $(11.38 \%),(12.72 \%), \quad(12.88 \%)$ respectively. These results show that motivation of the audit firm's employees form the most important measure for any business success whether an industrial, service and not for profit organizations. Relating the provision of quality service with employees' prospect of becoming partner would ensure continuity of provision of good quality audit services. The availability of continued professional education (CPE) for all levels of auditors whether seniors, auditors and trainees would result in the provision of high quality services especially if such CPE would concentrate on the updates in accounting and auditing standards as well as latest tools for IT audit. Finally, the respondents to the survey confirmed the importance of partners and seniors managers cooperating to prepare a policy for motivating employees through targets including good relation with clients and prospective clients as well as designing good financial packages for targets achieved. Qualifications of employees, motivating the employees through the prospect of becoming partner, firm providing new services and the implementation of employee evaluation forms represent the other elements thought by the respondents to be of importance. It seems that respondents did not allow for the provisions of new services by the audit firm except after employees are fully satisfied financially leading to the growth of the auditing firm. One interpretation of such results would be the reflection of the bad economic and political situation in the Egyptian environment since the Egyptian revolution in 2011 resulting in uncertainty concerning employees' future remuneration and their incentives: 
Table (2): Reliability and intrinsic validity for research variables

\begin{tabular}{|c|l|c|c|}
\hline No & \multicolumn{1}{|c|}{ Dimension } & $\begin{array}{c}\text { Reliability } \\
\text { coefficient } \\
\text { (Cronbach's } \\
\text { Alpha) }\end{array}$ & $\begin{array}{c}\text { intrinsic } \\
\text { validity }\end{array}$ \\
\hline 1 & Learning and growth perspective. & 0.850 & 0.9219 \\
\hline 2 & Internai business process perspective. & 0.844 & 0.9187 \\
\hline 3 & Financial perspective & 0.820 & 0.9055 \\
\hline 4 & Client perspective & 0.892 & 0.9444 \\
\hline 5 & Corporate Ethics perspective & 0.887 & 0.9418 \\
\hline \multicolumn{2}{|c|}{ Total } & 0.927 & 0.9628 \\
\hline
\end{tabular}

\section{2- Descriptive analysis}

The analyzed data is based on descriptive statistics using the mean, standard deviations, coefficient of variation and ranking (nonparametric statistical analysis using Wilcoxon test and Wilcoxon signed rank test). The descriptive analysis using the Likert rating scale would help to determine whether the general tendency of the responses is toward agreement, neutrality, or disagreement. Table (3) shows the importance of the five components of the proposed BSC with a mean that is greater than 4 . The rank shows the consensus on the five components among the survey respondents according to the values of the Co-efficient of variation. This indicates the importance of those dimensions from the auditors' perspectives. All these dimensions relate to how the audit firms would ensure its continued success by understanding the needs of their clients, how to ensure appropriate growth in the audit firm and means by which audit firms can protect themselves from legal liabilities and maintain their reputation.

Table (3): Descriptive statistics for the five perspectives of the model

\begin{tabular}{|c|l|c|c|c|c|}
\hline NO. & \multicolumn{1}{|c|}{ statements } & MEAN & SD & CV & RANK \\
\hline 1 & $\begin{array}{l}\text { Learning and growth } \\
\text { perspective. }\end{array}$ & 4.2616 & 0.32755 & 7.69 & $\mathbf{1}$ \\
\hline $\mathbf{2}$ & $\begin{array}{l}\text { Internal business process } \\
\text { perspective. }\end{array}$ & 4.2071 & 0.38565 & 9.17 & $\mathbf{2}$ \\
\hline $\mathbf{3}$ & Financial perspective & 4.1112 & 0.42292 & 10.29 & $\mathbf{3}$ \\
\hline $\mathbf{4}$ & Client perspective & 4.1041 & 0.48560 & 11.83 & $\mathbf{4}$ \\
\hline $\mathbf{5}$ & Corporate Ethics perspective & 4.1544 & 0.54227 & 13.05 & $\mathbf{5}$ \\
\hline
\end{tabular}


The participation form was sent to 14 hospitals responded positively in the first phase of the jurvey ( $81 \%$ response rate). The main reasons they cited for non-resjonse was the lack of time and the fact that answering questionnaires was not one of their top priorities. The hospitals that completed the participation forms were sent the questionnaire.

This section examines Egyptian auditors' perceptions regarding the proposed balanced scorecard for auditing firms. Moreover, Egyptian auditors' perceptions regarding the impact of the various components of the proposed BSC on the performance of the audit firms are also analyzed. The study is conducted with the following three objectives: (1) examine whether the proposed BSC is accepted for application by auditors in a developing country; (2) examine whether the suggested measures in the various components of the BSC are likely to help auditors assess their performance and the quality of their work; (3) examine based on auditors' perceptions whether audit quality/performance could be improved through the application of the proposed BSC in an auditing firm. The responses to research questions will provide supported evidence regarding the importance and benefits of the components of the proposed BSC and its role toward improving the performance of the audit process in a developing country environment.

1- Reliability and intrinsic validity for research variables: According to Table (2), researcher find out that reliability coefficient and intrinsic validity for research dimensions representing the components of the proposed balanced scorecard are (0.9219), (0.9187), (0.9055), (0.9444), and (0.9418) respectively. The results indicate the existence of a highly internal consistency based on the average inter-item correlation. The three dimensions with highly Reliability coefficients are: Client perspective, Corporate Ethics perspective, and Learning and growth perspective, with Reliability coefficient $(0.892),(0.887)$, and $(0.850)$ respectively. 


\begin{tabular}{|c|c|c|}
\hline Perspective & Objectives & Measures \\
\hline $\begin{array}{l}\text { Corporate } \\
\text { Ethics }\end{array}$ & $\begin{array}{l}\text { Adherence To } \\
\text { Profession's Ethical } \\
\text { Values }\end{array}$ & 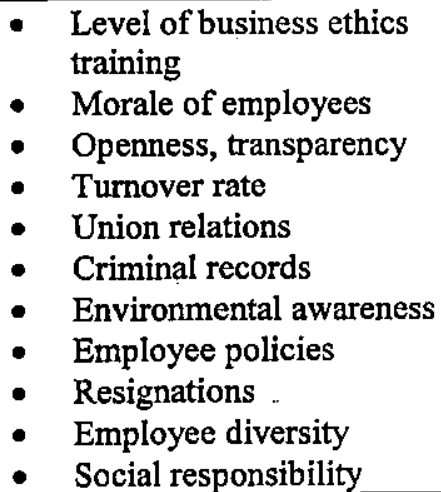 \\
\hline
\end{tabular}

\section{Statistical Analysis:}

\section{Sample Characteristics and Data Collection}

The sample surveyed included four auditing firms. The researcher chose two Big 4 auditing firms and two of medium size auditing firms in order to assess better the strict environment of auditing firms and to conform with the requirements of the research. The auditing firms have better audit quality departments and good internal control system, due to the restriction of complying with the auditing standards and legal requirement by the oversight boards of the profession. The criteria used for the selection of the auditing firms where both our accessibility and reputation. The research was conducted between in two phases.

Specifically, in the first phase participation form, accompanied by a cover letter where we made a brief reference of the main goals of the study, was sent to the selected auditing firms. The auditing manager executives have been asked to indicate the type(s) of quality control system(s) and its components, as well as to state correspondence information in order to address the survey questionnaire, in case they were interested. In the second phase of the research, the survey questionnaire was designed and sent to the sampled hospitals. More specifically, interviews were conducted with auditing manager executives who had a long experience in practices in order to make sure that the questionnaires' content was easy to understand. Through this testing we managed to account for omissions or vagueness in the expressions used to formulate the questions. 


\begin{tabular}{|c|c|c|}
\hline Perspective - & Objectives & Measures \\
\hline Financials & $\begin{array}{l}\text { The ability oi the } \\
\text { company to achieve } \\
\text { specific financial } \\
\text { objective } \\
\vdots \\
\end{array}$ & 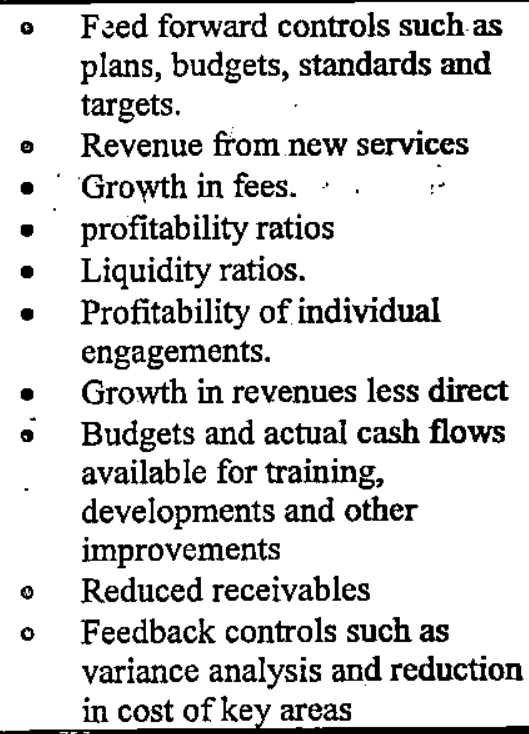 \\
\hline Client & $\begin{array}{l}\text { 1- Client satisfaction: } \\
\text { 2- Clients' growth and } \\
\text { retention: }\end{array}$ & $\begin{array}{l}\text { - Customer satisfaction feedback } \\
\text { form. } \\
\text { - Client complaints. } \\
\text { - Clients have easy access to } \\
\text { partners for any enquiries or } \\
\text { advise. } \\
\text { - Reasonableness of the audit } \\
\text { duration from the client's } \\
\text { viewpoint } \\
\text { - Providing timely updates on } \\
\text { the progress of the audit } \\
\text { - Presence of a "liaison" point of } \\
\text { contact between the firm and } \\
\text { client. } \\
\text { - Client's acceptance of the fees } \\
\text { charged. } \\
\text { - } \text { Brand awareness. } \\
\text { Customer retention (years of } \\
\text { audit) and repeated revenues } \\
\text { from the same client for other } \\
\text { services offered (if within the } \\
\text { standards). } \\
\therefore \quad \text { Percentage of new customers. } \\
\text { Customer referral. } \\
\text { Success or failure of project } \\
\text { tendering. } \\
\text { - Larket share } \\
\text { Lost clients. } \\
\text { Number of new clients }\end{array}$ \\
\hline
\end{tabular}




\begin{tabular}{|c|c|c|c|}
\hline Perspective & Objective & & Measures \\
\hline $\begin{array}{l}\text { Internal } \\
\text { business } \\
\text { process }\end{array}$ & $\begin{array}{l}\text { 1-Pre audit } \\
\text { requirements } \\
\text { 2- Quality of auc } \\
\text { service (engager } \\
\text { performance) } \\
\text { 3-Post audit } \\
\text { evaluations }\end{array}$ & $\begin{array}{l}\text { lit } \\
\text { nent }\end{array}$ & 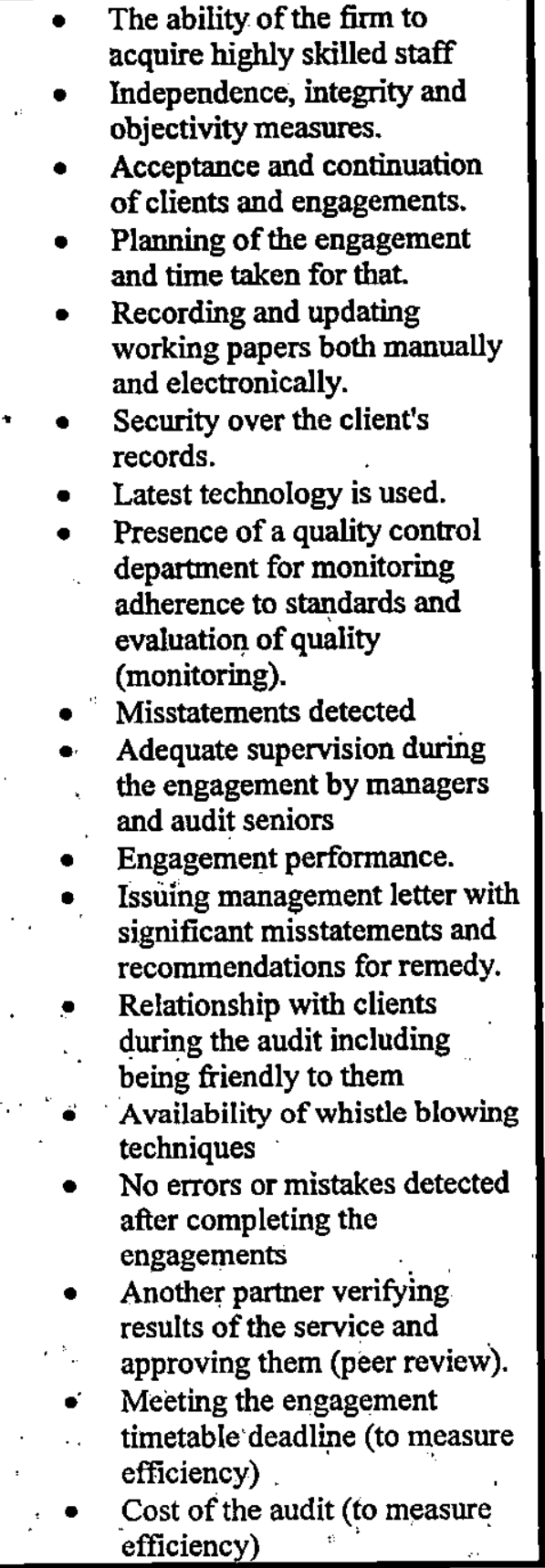 \\
\hline
\end{tabular}


Table 1: The perspèctives and measures of proposed BSC model for Auditing Firms






\section{8}

practicality of the proposed elements, budgets are planned for recruiting, developments, training, salaries and other expenditures each year. Feedback controls are achieved by comparing those figures to the budgets or to last year's results. Expected revenue per engagement and "recovery rates" are also calculated. Revenues from new services are analysed and revenues from ordinary services broken down by category and line of business. Moreover, cost per auditor is calculated using time sheet filled by every auditor multiplied by applicable hourly rate compiled to reach cost per audit teams.

Furthermore, the new added dimension by the researcher, the fifth component which is Corporate Ethics. It is an important component of the BSC and an important contribution of this research. The corporate ethics in auditing firms is very essential and it can be used to measure the adherence to profession's ethical values. Due to range of auditing services and recent corporate collapses, attention has been drawn to ethical standards accepted within the accounting and auditing profession (Jackling, et al 2007). Knowledge of ethics can help accountants and auditors to overcome ethical dilemmas, allowing for the right choice that it will benefit the company, as well as the public who relies on the auditor's reporting. (Stuart, Iris 2004). The big 4 audit firm aims to be a productive member of the community through employing several techniques and adhering to corporate ethics. It audits for free a number of not for profit organizations that aim at serving people such as the organization for cancer research, heart diseases...etc. and donates to them both in monetary and in kind forms, it pays taxes regularly and on time, creates job and recruits annually and basically provides value added services to the economy and financial community through its high quality audits.

Table 1 presents the integrated ideas from the initial BSC developed from the literature, the results of the case studies, and auditing quality control standards (ISA 220). It consists of 5 elements: learning and growth which comprises elements to develop personnel, implement sound information system and growth, internal business process concerned with the quality of development of audit process at its three stages: pre, during and post engagement, clients and measures of their satisfaction, financials measuring financial positions and the fifth element, corporate ethics, is suggested. Corporate ethics measure the firm's performance in relation to society or community (Tsamenyi et al., 2010). 
satisfaction questionnaires to the highest position at the client's firm requesting response direr ily to the firm's principal partner without the knowledge of the audit partner who is in charge. This is a dual tool used to evaluate the : partner simultaneously with. measuring satisfaction on areas such as reasonableness of audit duration, value added by the service, behavior of personnel on site. It is a five points Likert scale with five being excellent. Additionally, all clients are given a list of other numbers to contact should they have any queries. The firm sets the fees and periodically request raising them which if the client approves this is interpreted as an appreciation of its efforts. Another approach utilizes direct calls made by the managing partner to a list of clients arranging for a meeting to discuss satisfaction. This is mainly used with those clients too busy to fill in questionnaires. Lastly, outsourcing is applied using specialized institutes. Eccles, (1991) confirmed the growing popularity of using questionnaires and outsourcing to measure customer satisfaction. While some researcher view brand awareness as a success indicator (Kaplan and Norton, 1996a) particularly relevant to the case of a Big 4 firm yet a possible interpretation suggests clients may contract with those big 4 firms if they are large thus require a large firm to audit them not directly because it is one of the Big 4 . Similarly; high fees charged may not be indication of success but a reflection of efforts exerted in conjunction with client size.

The Fourth important component is financials that can be measured by each audit firm through its sophisticated information system. A CPA firm should measure operating profit for every audit team as revenues less direct costs. This is then piled up to reach operating profit for every executive in charge of a cluster of audit teams which is too accumulated reaching profits per senior partner. Overheads and partner's remuneration are then deducted attaining firm's profit. Such process is repeated quarterly till reaching year end profits which is compared with budgets and last year's figures for the purpose of amending any significant unfavorable variances and for use in gross and net profits margins computations. As Mohamed and Mayada (2015) indicated through their case studies "a list of total revenues received from each client, decompose total revenues into its constituents from audit, tax, review and consultancy services and. compare those with last year's to determine growth, revenue from each service is matched against its expenses including applicable taxes to calculate its profits and again compare it with last year and a monthly statement of all expenses is prepared". With respect to the 


\section{6}

needed. In addition, annual quality control visits from the headquarters of the affiliated firm further assures quality is maintained for all the mentioned elements.

A strategy and plan is developed for every engagement and a budget prepared (Fitzgerald and Brignall, 1991). Estimated hours needed are multiplied by chargeable rate applicable to every auditor on the team reaching budgeted revenues necessary to cover costs. The actual times and revenues received are benchmarked against this to compute the "recovery rate" and evaluate on time deliveries. Each CPA Firm specifies a recovery rate ranging from $50 \%$ up to $80 \%$. Any deviations could be attributable to an unrealistic plan, client failing to submit records on time or problems related to traffic time wasted to get to and from client. Also, the firm may be "over auditing" by looking deep into the client's files, accumulating various samples and evidences.

An important-component of internal process in a balanced scorecard is the existence of an information systems' capabilities in a CPA firm. The firm sets up sophisticated information system containing the company's files and records, highly secured customer database, a catalogued (hard and soft copy) library holding up to date information on -auditing standards, regulations, laws and references. In addition, state of art electronic auditing tools such as computer assisted auditing tools (CAATs) is implemented (as explained by Gray and Manson, 2007).Independence is priceless for any audit firm (Gray and Manson, 2007). The firm must have strict measures for circumventing any breaches through an independence deceleration form signed by every auditor on the team in addition to closely supervising employees during work: Clients are assessed on the basis of risk, previous year's reports; personnel's comment, cost/benefit analysis ...etc. informally by the executive partners. Engagement performance is measured through both internal and international quality reviewers, mainly with reference to working papers, and several checklists are used to ensure standards were followed, all documents are present, sample sizes appropriates, plan was followed...etc. Official management letter printed on the firm's letterhead is addressed to each client at the end of each engagement expressing all recommendations identified and adding value to their clients' business.

The third important component of the proposed $\mathrm{BSC}$ is client. In the big 4 CPA firm formal and written procedures for reaching and measuring customers' satisfaction include sending customers' 
nominated for promotion or managers are also assessed stressing on characteristics such ás leadership, communication skills and qualifications. Compensation, directing employees, supervision, recommending specific trainings, costs control and assuring compliance with professional standards exists in auditing firms.

Growth measures may include the number of customers or total revenues received. These figures are compared with budget and last year's results identifying any problems affecting the firm's growth such as if a client sued the firm, staff problems occurred or a partner is unhappy...etc. In addition, it measures its ranking with respect to other audit firms operating in the market using the internationally agreed upon measure "total billings" received by international CPA firms. Further, time to develop new products is critical to growth of firms (Kaplan and Norton, 1996a). Most of the CPA firms adopt a principle to serve all clients from the time they start thinking of investment opportunities until they reach end of the company life. Moreover, the CPA firm ensures innovated services offered are conforming to independence standards since the provision of some service to audit clients such as bookkeeping are prohibited whereas others are allowed only if the audit committee agrees (Gray and Manson, 2007; Arens et al., 2013).

The second important component of suggested balanced scorecard is Internal Business Process, CPA firm measures internal business through effectiveness and efficiency related to the delivery of high quality audit with an appropriate report. This is assessed with reference to the detailed documented working papers describing every single step of the audit and mandatory to be prepared in both manual and electronic formats. Multi layered and strict quality control procedures should be in place to monitor effectiveness including adherence to work agenda maintained by every employees (soft \& hard). The firm should ensure continuously recording and updating the working papers. Every single audit must have its working paper reviewed by a partner. Any "significant audit" with respect to size or risk is to be thoroughily read and signed by the managing partner. All listed companies audited must have their working paper additionally reviewed by a "conquering" partner who was not involved at any stage of the audit to ensure the audit report is fully supported by the working papers. More and above, internal quality control department reviews a selection of client's papers while also assuring all audit files are in place, required signatures are present and no improvements are 


\section{4}

last level was developed equipped with a more accurate tool which named strategy map.

Based on the above discussion of the nature and component of BSC, a number of research questions can be addressed within the audit services. They are concerned with what the firm develops rather than how it develops its own performance measurement. Research is focusing extensively on the processes and procedures to be taken by auditing firms to maintain the quality of their output yet and being able to evaluate their own performance in way that is more comprehensive. Further, proposing improvements to their performance measurement and managements systems could prove beneficial not only to the auditing profession but to all those concerned with its effectiveness including the economic society.

The proposed Balanced Scorecard model for Audit Firms.

There are five elements, which may be included in a balanced scorecard for auditing firms learning and growth, Internal Business Process, Customers, financial and corporate ethics.

The first important component is learning and growth characteristics would include the assessment of the qualifications and experience of the employees in CPA firm. Audit firms should measure their performance mainly with respect to its personnel. Sophisticated and detailed procedures are implemented to ensure employees perform as intended, are knowledgeable and presentable. Further, it values more the quality of its output necessitating thorough working papers be prepared for every engagement and every auditor. It is believed that it is very practical of firms to measure all those aspects since they do in fact lead to success. Qualification of professionals are measured in terms of international certificates received, average years of audit experience and calculating percentages of qualified professionals relative to the less qualified ones. At the same time, measuring employees competence may rely on factors such as awareness of the job's tasks, work quality, speed of concluding work, following plans, continuously updating working papers, trustworthiness, behaviour, self-motivation, attendance, punctuality, appearance ..Etc. Each factor is weighted and a score calculated. Auditors are also evaluated after every engagement where they give a full report on all tasks performed, duration consumed and expenses incurred such as travel. This should be fully reviewed by their supervisors and quality control manager to assess. the auditor's performance and is also used for. assessing engagement's plan and expected costs formulated. Employees 
Brignal, 1991), and the balanced. Scorecard (Kaplan and Norton, 1992).

Although extensive research has been undertaken for performance measurement in manufacturing sector. services are those industries: treating people or offering them goods and services ranging from education, transportation, communication, heath care and others included in sections 6 to 9 in (SIC) Standard Industry Classification (Johnston, 1988).Professional services such as auditing require high contact time with customers who need a customized services, the focus is on the process rather than the output and is based on people who are empowered. At the other extreme, mass services such as . transportation feature low contact time or customization, is equipment and product oriented and depends on back office people given low discretion. At the interim side come service shops such as postal (Fitzgerald and Brignall, 1991; Silvestro et al., 1992). Performance measurement is more challenging for services which are intangible thus difficult to measure and control. Further, the output of service organizations is heterogeneous varying across employees and customers preventing consistency in evaluations. Moreover, the production and consumption of services occur simultaneously where customers are present at the production time. Consequently some services cannot be measured, inspected or counted prior to sale neither can wastes of knowledge and output results be measured and eliminated. Similarly, if customers are not satisfied with the production process itself that they see they may not be satisfied with the final output.

The importance and use of the balanced scorecard as a tool for performance evaluation has been recognized in the management accounting literature (Kaplan and Norton, 1992, 1996b; Simon and Koh, 2001; Cohen et al 2005, The balanced scorecard Institute, 2010). However, few studies discussed its development and implementation in professional services. BSC looks at the firm's performance from four perspectives the financial, customer satisfaction, internal business process and learning and growth.

Kaplan and Norton (1996a) added new metrics to the second: generation of BSC in order to increase strategic communication and created the third generation of BSC based on these changes. In the late 1990 , two other metrics, strategic destination and strategic themes were added to BSC. In addition cause and effect relationship model in 
Scapens et al., 2003; Marr and Schiuma, 2003; Marr and Neely, 2001;Neeley, 2005; Paranjape et al., 2006; Taticchi et al., 2010). The importance of performance measurement has been discussed widely in accounting literature. Lynch and Cross (1991, pp.20-23) state that performance measurement is" the single most powerful tool to ensure success of business strategies" and that "setting and attaining a few key performance measures will help ensure that all levels of the organization stay on track and pull together behind the corporate engine before competition beats them to it ".A number of other studies highlighted such importance confirming the need for organizations to develop and successfully implement performance measurement systems which support their strategies using financial and non-. financial (i.e. customer satisfaction, internal process and interactive learning process) and communicating such measures not only to higher level but also lower level management (Berliner and Brimson, 1998; Marr and Neely, 2001, Marr and Schiuma, 2003; Neely, 1999 and 2005; Sharma et al., 2005, Yazdifar and Tsamenyi, 2005; Simons, 2000; Sousa and Aspinwall, 2010).

Traditionally, firms are measuring performance financially in terms of bottom line result: profits and other related measures such as budgets, standard costing, and $\mathrm{ABC}$ costing. (Fitzgerald, 2007; Fitzgerald and Brignall, 1991; Foster, 1986; Horngren et al., 2005; Johnson and Kaplan, 1987; Simons, 2000). The failures of traditional measures gave rise to two schools of thoughts (Fitzgerald, 2007): the first approach, the shareholder's value approach which trusts that measuring and rewarding activities that create shareholder value ultimately enhances their wealth (Cooper et al., 2001) preferring profits-based measures including Residual Income and Economic Value Added (EVA): The second approach, Stakeholders approach supports integrating financial measures with nonfinancial ones on the grounds that no single measure, could be sufficient enough to capture neither all facets of performance nor direct attention to problems(Hope and Fraser, 2001; Hoque, 2003;Scapens et al., 2003; Yazdifar and Tsamenyi, 2005; Horngren et al., 2005 and Zimmermann, 2009). Firms need balanced between both financial and nonfinancial indicators to link performance measures to strategy and build competitive advantage (Kaplan and Norton, 1992). Numerous frameworks have been developed to address such balanced including: Performance Prism (Neely et al., 2002), SMART pyramid (Cross and Lynch, 1992), Results and Determination framework (Fitgerald and 
Since the balanced scorecard is a flexible measurement tool whereas auditing on the other and is a restrictive profession a research question is addressed assessing whether audit firms would be able to adopt and benefit from a balanced scorecard needed to integrate the internal objectives of the firm with the requirements of the external regulatory environment. Based on a previous research identifying challenges facing performance measurement systems in auditing firms, the current research develops a framework of a proposed BSC for auditing firms and tests such BSC measures in enhancing the performance of the audit work (Moahmed and Mayada, 2015).

The professional services have unique characteristics associated with the professional knowledge considered the core resource for their service success and it represents both the input and output in their production process. Moreover, professional services rely on other firms output as their intermediate input for the provided professional services. This is considered a main and important difference between these organizations and the manufacturing where its output is looked at as consumer product. Thus, a different role is played by professional services compared to manufacturing requiring a different means to assess their service outputs (Nachum, 1999). Thus, this research is conducted to investigate the design and practice of performance measurements of the audit firms specifically and has a number of contributions to the auditing and performance evaluation literature. First, the research reviews the literature related to the nature and type of performance measurement systems used in professional firms and whether any of them follows a BSC or similar forms of such systems. Second, the research provides a scientific analysis of the appropriate components and detailed measures of a BSC in professional audit firms adding the fifth perspective, which is the corporate ethics to fit with the nature of the audit firms. This perspective is unique for the auditing firms as the type of service that is provided by the auditing firms is mainly based on ethics, integrity, and honesty. Third, the research investigates how the use of the proposed BSC would enhance the performance of audit firms compared with the traditional performance systems.

\section{Balanced Scorecard in Professional Services organizations}

Performance measurement has gotten "great interest and attention in the last two decades with thousands of researches conducted in the area (Abdul Khalid, 2000; Johnston et al., 2002; Neely et al. 2002; 


\section{Strategic Management Accounting}

The literature on SMA has expanded rapidly since the early 1980s in the light of the growing criticism of traditional accounting approaches. (Hoffjan \& Wömpener, 2006; Fincham, \& Roslender 2003). The literature on SMA showed that there are three general characteristics that have emerged over time. The first is the notion of an external focus; the second is that SMA has a long term, forward looking orientation; the third is that there is now a provision for the use of both financial and non-financial information for decision-making purposes (Cadez \& Guilding, 2007). This last development alters significantly, what was the preyailing notion in management accounting: that accounting data or financial numbers was the only real management tool for effective internal organizational decisionmaking.

To understand the benefits sought by SMA proponents it is necessary to look inside the organization, whereas information on activities and performance measures is available internally. Using a strategic management tools is possible to interface the set of benefit producing attributes sought by managers with performance measures associated with providing these benefits. It is important to provide these benefits as cost effectively as possible, since only efficient institutions, each of which yield the maximum amount of a specific bundle of benefits (Services and Products) for the most effective performance with the minimum cost (Bromwich, 1992).

Attribute performance, therefore, constitutes an additional approach to performance measurement, but one that is quite distinct among all strategic management approaches is the BSC (Kaplan and Norton, 1996b). The researcher will emphasize next on the balanced scorecard as to comply with the objectives of the research.

\section{Balanced Scorecard}

The balanced scorecard is a strategic performance measurement system developed by Kaplan and Norton in 1992. BSC Focus on multi-dimensions set of performance elements that optimize and achieve the-measurement process in accordance with the principle "what gets measures gets managed" and the rest ignored(Kaplan and Norton, 1996a). For instance, audit firms should accept only engagements that are profitable to prevent the audit failures (Ziegenfuss, 2000). 
H2: The developed measures in the proposed model of BSC for audit firms will enhance the ex sected performance of the audit work H3: The suggested mode 1 is valid in the Egyptian auditing firms.

\section{Introduction:}

The classical response of the auditing profession to business scandals is restricted to standards and rules around auditing firms with the hope that they will be able to improve their performance. For example, in the U.S., Sarbanes Oxley Act in 2002 had been issued following Enron's failure (Arens et al., 2013). Performance measures and other control elements are essential for decision making and for efficient and effective controlling of organizations (Simons, 2000 and Neely et al, 2002). Goal setting, strategy to be developed, benchmarking, feedback and follow up would help in the process of improving the performance of organizations in different industries (Otley and Bery, 1998). The success of every organization is affected by the proper allocation of economic resources and right decision, which require specific and clear performance, measures (Merchant \& Van der Stede, 2007).

Despite the importance of performance measurement, yet auditing standards give little attention to how auditing firms should be managed. According to professional auditing bodies, audit firms are successful enough if they perform "quality" audit. In fact in order to do a quality audit, auditing firms are in need for a system to measure its own performance. This system is not just to measure the quality of its output particularly but to align the performance of the whole firm. Consequently, there should be monitoring system of quality assurance to assure the firm is meeting its mission while adhering to strict auditing standards. This system may be composed of (1) supervision, (2) internal reviews, (3) external reviews and (4) performance and benchmarking. External peer review and internal reviews by quality control partner, to be with high importance along with performance measurement and benchmarking that started to gain more attention in recent years (Ziegenfuss, 2000). Such performance measurement system should include important elements of performance, such as customer satisfaction or financial viability of conducting the audit: which if not properly adhered to may lead to yet another audit failure. This is why the researcher is proposing the use of an integrated performance measurement approach such as the balanced'scorecard. : 


\section{Keywords:}

Auditing, audit firms, auditing balanced scorecard, performance measurement, Egypt.

\section{Research Problems:}

The auditing firms as one type of the service companies has a special nature that make the performance evaluation process inside it very challenging. Due to the special nature of the services provided by the auditing firms and the restrictions imposed on them through adhering to standards and regulations; a special performance measurement system to comply with all of these issues is needed. The use of the new Strategic management accounting approaches is very essential and effective in such cases. One of the most famous and tested approaches within the strategic management accounting literature is the balanced scorecard. The research tried to face this change by suggesting a new framework that is based in its core on the BSC but with modifications to be adapted for the auditing firms. The research tried to validate this framework in the Egyptian auditing firms.

\section{Research Objectives:}

The auditing firms have a special nature due to the nature of its operations. The research is proposing an auditing balanced scorecard model to enhance and improve the performance of the auditing firms in Egypt. The research proposed a five constructs for the auditing balanced scorecard model to be applied in the auditing firms. The research investigated the suitability of theses constructs and measures for the auditing firms. The research is facing the challenges of designing a comprehensive performance evaluation system for auditing firnts.

This research aims at addressing and achieving the following objectives:

- To identify the different components of the balanced scorecard model in auditing firms rather than in any other service firms.

- To test the measures developed in the proposed balanced scorecard model in enhancing the expected performance of the auditing firms.

- To validate the suggested model in the Egyptian auditing firms.

\section{Hypotheses:}

H1: The components of the BSC for auditing firms will be different from the BSC for any service organization 


\section{Myth of Performance Evaluation in Auditing Firms-tevidence from Egypt}

Mohamed Samy El-Deeb, Ph.D. Modern Sciences and Arts University, Egypt

Moh.eldeeb2@hotmail.com, msamy@msa.eun.eg

\section{Abstract:}

Many existing researches addresses performance measurement in industries rather than professional services firms. The auditing firms are one of the main service firms in relation to the accounting profession in the world. This research among the first to provide insight into strategic management accounting performance measurement systems to be applied in auditing firms. The research proposed a proposed auditing balanced scorecard (BSC) for. performance measurement in auditing firms. A review of the literature for performance evaluation using BSC in service industries have been done to identify needed measures for the development of a proposed BSC framework for auditing firms as one of the service firms. The proposed model was verified by a questionnaire that distributed upon auditors in four auditing firms including two of the big four and two of the medium size-auditing firms to assess their opinions concerning the proposed BSC framework. The empirical analysis used descriptive analysis and regression analysis to analyze the data collection. The results of the statistical analysis showed a verification of the research hypothesis and verified the compatibility of the model's constructs and measures of the proposed model for the auditing firms. The statistical analysis also, validated the practicality of adopting such proposed framework in the Egyptian auditing firms.

\section{Research Limitations :}

The results of the research based on a limited survey that were distributed on number of auditing firms in Egypt. Our research participants are from four auditing firms including two of the big 4 and 2 of the medium size auditing firms in Egypt. It is recognized that further research is necessary to establish the exact nature of the causal linkages between proposed performance measures and strategic view of the auditing firms and also, to gain insights into practice elsewhere. Auditing balanced scorecard model was empirically examined within auditing firms to validate it by matching the suggested elements with the prevailing practices ascertaining their pràcticality. 


\title{
Myth of Performance Evaluation in Auditing Firms- Evidence from Egypt
}

\author{
Dr. Mohamed Samy El-Deeb \\ Modern Science and Arts University
}

